\title{
Situating Mindfulness, Part 2: Early Buddhist Soteriology
}

\author{
Bhikkhu Anālayo ${ }^{1}$
}

Accepted: 22 June 2021 / Published online: 2 October 2021

(c) The Author(s) 2021

\begin{abstract}
As the second of three articles, the present essay continues to explore the character of selected aspects of early Buddhism in order to assess its potential relevance as a reference point for those engaged in research on mindfulness in psychology. The exploration, which proceeds in critical dialogue with suggestions made by Donald Lopez Jr. and Evan Thompson, covers the topics of the role of mindfulness as a means for progress to awakening, the path to and the realization of awakening, the implications of the doctrines of not self and of the four noble truths, and the centrality of meditation in early Buddhism. The proposed conclusion is that a deserved criticism of a tendency toward unbalanced presentations of Buddhist thought, so as to be palatable to Western preferences, has gone overboard in the opposite direction, resulting in inaccurate evaluations and exaggerated claims that call for a correction and a sober reassessment of the actual evidence. Such reassessment shows that there is considerable room for an open dialogue between contemporary psychology and Buddhist meditation practice traditions regarding their common ground in the aspiration to understand the workings of the mind with a view to alleviating unnecessary suffering.
\end{abstract}

Keyword Awakening · bodhi $\cdot$ Four noble truths $\cdot$ Mindfulness $\cdot$ Nirvana $\cdot$ Not self $\cdot$ The path to awakening $\cdot$ Self-reliance $\cdot$ The unconditioned

An exploration of some key aspects of early Buddhist thought from the viewpoint of their possible conflict with Western scientific rationalism shows that the attribution of omniscience to the Buddha is a later development and hence need not be considered as an indispensable element of Buddhist thought (Anālayo 2021c). His role as a teacher, rather than requiring the display of infallible knowledge about details of the physical world, is much rather one of disclosing the constructed nature of the subjective experience of the world. Keeping additionally in mind the oral nature of the teachings attributed by tradition to the historical Buddha and his disciples helps to put into perspective the employment of staggering numbers or of other cosmological details that are not in keeping with current knowledge of the physical world, in the understanding that these served a literary function in the ancient Indian oral setting. Relevant passages portray the Buddha as having taken on the role of a teacher in the ancient Indian setting with remarkable openness, explicitly inviting prospective disciples to put his claim to being fully

\section{Bhikkhu Anālayo}

1 Barre Center for Buddhist Studies, 149 Lockwood Road, Barre, MA 01005, USA awakened to the test. The attitude conveyed in this way can be understood to leave considerable room for personal freedom and uninhibited investigation.

\section{Mindfulness and Awakening}

A central tool for investigation and for developing the type of self-reliance that the early discourses explicitly commend relates to the notion of refuge, which in traditional forms of Buddhism is the way to express one's status as a Buddhist. The relevant commendation presents the practice of the four establishments of mindfulness as a key element in learning to take refuge in oneself (Anālayo 2015, 2021c). In its early Buddhist setting, the chief purpose of cultivating these four establishments of mindfulness (satipatthāna, smrtyupasthāna, 念處, dran pa nye bar gzhag pa) is to lead to awakening. This finds expression in the Satipatthāna-sutta and its parallels in the following manner:

This is the direct path for the purification of living beings, for the surmounting of sorrow and lamentation, for the disappearance of distress and displeasure, for 
acquiring the true method, for the realization of Nirvana, namely the four establishments of mindfulness. (MN 10: ekāyano ayam ... maggo sattānam visuddhiya sokaparidevānam samatikkamāya dukkhadomanassānam atthañgamāya ñāyassa adhigamāya nibbānassa sacchikiriyāya yad idam cattāro satipațțānā).

There is a single path for the purification of living beings, for going beyond sorrow and fear, for eradicating distress and affliction, for abandoning weeping and tears, for attaining the right Dharma, namely the four establishments of mindfulness.

(MĀ 98: 有一道淨眾生, 度憂畏, 滅苦惱, 斷啼哭, 得 正法, 謂四念處).

There is a one-going path for the purification of the actions of living beings, for removing worry and sorrow, for being without afflictions, for attaining great knowledge and wisdom, for accomplishing the realization of Nirvana, namely that one should abandon the five hindrances and attend to the four establishments of mindfulness.

(EA 12.1: 有一入道, 淨眾生行, 除去愁憂, 無有諸 惱, 得大智慧, 成泥洹證, 所謂當滅五蓋, 思惟四意 止).

Although the Madhyama-ägama version does not explicitly mention Nirvana, the same is clearly implicit in its presentation; in fact, the discourse continues after the above extract by indicating that all those who reached full awakening did so by cultivating the four establishments of mindfulness. Given the centrality of realizing Nirvana that emerges in this way, the implications of such realization are of considerable relevance to the overall topic of situating mindfulness.

The role of the four establishments of mindfulness in leading to liberation relates to the awakening factors, seven qualities whose presence in the mind facilitates the event of awakening. The first and foundational of these seven factors is mindfulness itself, which has the four establishments of mindfulness as its nutriment (SĀ 715 and Up 5037; the Pāli version SN 46.51 is less specific, see Anālayo 2020b, p. 222). A Pāli discourse and its parallel depict progress from an establishment of mindfulness to the gaining of liberating knowledge (SN 54.13 and SA 810 ), which takes place through the intermediary of cultivating the awakening factors. Such cultivation can be understood to facilitate awakening, in the sense of a stepping out of the craving-based constructed nature of the subjective experience of the world. For achieving such deconstruction, the awakening factors need to be cultivated in the following manner, illustrated with the example of mindfulness:
One cultivates the awakening factor of mindfulness in dependence on seclusion, in dependence on dispassion, and in dependence on cessation, culminating in letting go. (SN 54.13: satisambojjhañgam bhāveti vivekanissitam virāganissitam nirodhanissitam vossaggaparịnāmiṃ).

One cultivates the awakening factor of mindfulness supported by seclusion, supported by dispassion, and supported by cessation, leading to letting go.

(SĀ 810: 修念覺分依遠離, 依無欲, 依滅, 向於捨).

The parallels depict a cultivation of mindfulness (and of the other awakening factors) in reliance on the same three insight dimensions, with the purpose of leading to "letting go." This is what the cultivation of mindfulness seems to be meant to lead up to eventually, namely a comprehensive letting go that enables stepping out of the construction of experience. The detailed instructions on each establishment of mindfulness in the Satipatthanna-sutta and its parallels can be understood to serve the purpose of enabling such stepping out. In other words, these instructions are not just for the sake of inculcating doctrinal categories. Instead, the overarching purpose is best understood to lead to a complete transcendence of the whole world of experience.

The role of the doctrine, the Dharma, in this respect is comparable to a raft used for crossing over a strong river that one would otherwise not be able to traverse (MN 22, $M \bar{A}$ 200, EĀ 43.5, and Up 8029). It is indeed meaningful to rely on a raft for the purpose of crossing over. Once that has been achieved, however, the raft should be left behind. It would be meaningless to continue one's journey carrying along the raft. In the same way, so the reported instruction given by the Buddha goes, his disciples should be ready to let go of his teachings, once these have fulfilled their liberating purpose.

It is remarkable to find such an encouragement by the founder of a religious tradition to let go even of his teachings, which are reportedly considered by him to be merely a raft to provide support in crossing over.

\section{The Path and the Goal}

Regarding the relationship of the path of practice to the event of awakening, Thompson (2020, pp. 78 and 152) identified the following "fundamental generative enigma":

nirvana, in being the unconditioned, can't be the result of any cause and specifically can't be the result of any mental cause. But this implies that nirvana can't be the result of following the Buddhist path ... how is liberation possible if nirvana can't be the effect of any cause? ... Whatever is unconditioned can't be the result of any cause, and nothing can affect it. Therefore, no activ- 
ity, including meditation practice, can bring it about. So, how could awakening or nirvana be realizable in meditation or by following the Buddhist path?

At least as far as early Buddhism is concerned, the supposed enigma seems to rest on a misunderstanding. The top of the mountain is not the "result" of the path leading to it; it is not "brought about" by the path. Yet, this does not mean that following the path cannot lead to the top of the mountain. Awakening and the realization of Nirvana are not the "result" of the path of the four establishments of mindfulness; they are not "brought about" by the path of the four establishments of mindfulness. Yet, following the path of the four establishments of mindfulness can lead to awakening and the realization of Nirvana.

There is a need for steps to be taken within the realm of what is conditioned in order to lead up to a deconditioning. This is why the Satipatțanna-sutta and its parallels offer such detailed instructions, as a way of helping the individual practitioner in gradually removing those obstructions that prevent the breakthrough to Nirvana. The degree to which such details are needed depends in turn on the inner maturity of the individual practitioner. The famous story of Bāhiya shows how a non-Buddhist practitioner became an arahant on the spot during his first meeting with the Buddha (Ud 1.10). In this case, apparently involving someone of exceptionally high inner development, a brief instruction in "bare awareness" was enough to lead to completely letting go (Anālayo 2018, $2019 b)$. But the average practitioner needs a raft to cross over. At the same time, the raft has only an instrumental purpose; its function being fulfilled, it should be left behind.

A Pāli discourse (AN 4.175) reports the Buddha's chief disciple Sāriputta clarifying that making an end (of dukkha) does not happen just by means of knowledge or by means of conduct (or by means of both in combination). Nevertheless, one who has no knowledge or is bereft of conduct will be completely unable to make an end (of dukkha). The solution lies in understanding the merely instrumental function of knowledge and conduct. These are needed to lead up to the point where the breakthrough can take place. But holding on to them at that time will prevent the breakthrough from happening, as this requires completely letting go. The Buddha himself is on record for offering a similar indication in the following form:

I say that purity is not [reached] through a view, not through learning, not through knowledge, not through virtue and observances, and is it also not [reached] through the absence of a view, through the absence of learning, through the absence of knowledge, through the absence of virtue, and through the absence of observances; it is not in that way. Having relinquished these without grasping, peaceful and independent, one should not long for becoming.
(Sn 839: na dițthiyā na sutiyā na ñānena, sīlabbatenā pi na suddhim āha; adițthiyā assutiya a añaṇa asīlatā abbatā no pi tena. ete ca nissajja anuggahāya, santo anissāya bhavam na jappe).

One does not become wise by seeing and hearing and also does not become purified by being endowed with the practice of virtue; one does not become [free from] delusion by not seeing and hearing and also cannot purify oneself by being separated from the practice [of virtue]. There being such perceptions, one should relinquish them and not cling.

(T 198 (no. 9): 亦見聞不爲點, 戒行具未爲淨, 不見 聞亦不癡, 不離行可自淨. 有是想, 棄莫受).

The visitor hearing this explanation remained bewildered. This illustrates that for someone not well acquainted with Buddhist doctrine this can indeed seem puzzling. Yet, after further explanations that clarified the Buddha's position, according to the Pâli commentary the visitor even decided to go forth and became an arahant ( $\mathrm{Pj}$ II 548), thereby confirming to himself what it takes for the breakthrough to happen.

The same basic understanding of the relationship between the path and the goal finds reflection in the reply given in the Visuddhimagga precisely to the question of how Nirvana can be unconditioned yet reachable by the path, a reply which shows the continuity of the above perspective in later Buddhist tradition:

For [Nirvana] is indeed to be reached by the path, [although] it is not to be produced [by it].

(Vism 508: pattabbam eva h'etam maggena, na uppādetabbam).

\section{The Realization of Awakening and Not Self}

Regarding the awakening attained by others who follow the path taught by the Buddha, Lopez (2008, p. 140) reasoned:

Others, however, must rely on the teachings of the Buddha to experience enlightenment, and even then, that experience is not said to be self-validating. The Buddha's foremost disciples, Śāriputra and Maudgalyāyana, who flank him in so many paintings and statues, had to be informed by the Buddha that they had reached the stage of arhat.

This intriguing assertion comes without any reference to a source, making it difficult to determine where the idea may have originated that these two chief disciples became arahants/arhats without knowing to have reached full liberation (or that this exemplifies a general condition of disciples who reach the final goal). The instruction by the Buddha which, according to the Pāli commentarial tradition (Mp IV 44), led to Mahāmoggallāna/ 
Mahāmaudgalyāyana's realization of full awakening does not report his actual becoming an arahant/arhat (AN 7.58, MĀ 83, and $\mathrm{T}$ 47). This conveys the impression that his breakthrough should be understood to have happened after the Buddha left and for this reason was not reported in the versions of this discourse. In the case of Sāriputta/Sāriputra, however, his realization of the final goal is explicitly recorded, as it reportedly happened while being present when the Buddha was giving a teaching to a wanderer. None of the three discourse versions provide any indication that he needed the Buddha's help to know that he had become an arahant/arhat (MN 74, SA 969, and $\mathrm{SA}^{2} 203$ ). The conversion and attainment of the final goal of these two chief disciples has been studied in detail by Migot (1954), based on a broad range of different sources, yet without an indication that they needed help to know that they had become arahants/arhats.

Regarding the attainment of the final goal by arahants/ arhats in general, according to a recurrent description this involves not only liberating the mind from defilements, but also the direct personal knowledge of being liberated, described according to a standard formula in terms of having done what needed to be done and having gone beyond future rebirth. Here is an example:

The mind of one who knows like this and sees like this becomes liberated from the influx of sensuality, the mind also becomes liberated from the influx of becoming, and the mind also becomes liberated from the influx of ignorance. Being liberated, there is the knowledge of being liberated and one understands: Birth has been ended, the holy life has been lived, what had to be done has been done, there is no further for this state of existence.

(MN 27: tassa evam jānato evam passato kāmāsavā pi cittam vimuccati, bhavāsavā pi cittam vimuccati, avijjāsavā pi cittam vimuccati. vimuttasmim vimuttam iti ñānam hoti, khịnā jāti, vusitam brahmacariyaṃ, katam karaṇīyam, nāparam itthattāyā ti pajānāti).

The mind of one who knows like this and sees like this becomes liberated from the influx of sensuality, and the mind becomes liberated from the influx of becoming and the influx of ignorance. Being liberated, there is in turn the knowledge of being liberated and one understands as it really is: Birth has been ended, the holy life has been established, what had to be done has been done, there is no further experiencing of becoming.

(MĀ 146: 彼如是知, 如是見, 欲漏心解脫, 有漏, 無 明漏心解脫. 解脫已, 便知解脫: 生已盡, 梵行已立, 所作已辦, 不更受有, 知如真).

Such descriptions make it clear that the attainment of full awakening was seen as a self-validating experience, in the sense that one who has just become an arahant/arhat would know and not need to rely on someone else.

A key element of the realization of Nirvana is the deconstruction of any notion of a self. Already a stream-enterer is considered beyond upholding any view of a self. Regarding the early Buddhist doctrine of not self, Thompson (2020, p. 92) reasoned:

Many of the Vedic-Brahminical thinkers would agree that what the Buddha calls the 'five aggregates' are indeed not-self. They would say that the true self (atman) transcends the aggregates. The true self isn't the body, feeling, sense perception, volition, or sensory or mental consciousness, and it lies beyond them.

This then supposedly raises the question if "the Buddha's teaching is compatible with there being a self," or whether the Buddha's reasoning was that, "if there were a self, it would have to exist among the aggregates," or whether the Buddha just did not provide a positive or negative answer to the question about the existence of a self. The proposed reasoning appears to be based on a misunderstanding of the compass and implications of a realization of not self. Insight into not self includes self-notions in addition to the identification of an aggregate as a self. This can be seen in the following passage, which describes the level of understanding reached by a stream-enterer:

One does not regard form as the self, nor the self as possessed of form, nor form as in the self, nor the self as in form. One does not regard feeling tone as the self, nor the self as possessed of feeling tone, nor feeling tone as in the self, nor the self as in feeling tone. One does not regard perception as the self, nor the self as possessed of perception, nor perception as in the self, nor the self as in perception. One does not regard volitional formations as the self, nor the self as possessed of volitional formations, nor volitional formations as in the self, nor the self as in volitional formations. One does not regard consciousness as the self, nor the self as possessed of consciousness, nor consciousness as in the self, nor the self as in consciousness.

(MN 44: na rūpam attato samanupassati, na rūpavantam vā attānam, na attani vā rūpam, na rūpasmim vā attānam. na vedanam attato samanupassati, na vedanavantam vā attānam, na attani vā vedanaṃ, na vedanāya vā attānaṃ. na sañ̃nam attato samanupassati, na sañ̃̃avantam vā attānam, na attani

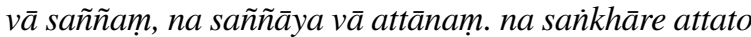
samanupassati, na san்khāravantam vā attānam, na attani vā saìkhāre, na san்khāresu vā attānam. na viñ̃ānam attato samanupassati, na viñ̃̃ānavantam vā attānam, na attani vā viñ̃̃ānam, na viñ̃āạasmim vā attānam). 
One does not see form as the self, does not see the self as possessing form, does not see form as contained within the self, does not see the self as contained within form; one does not see feeling tone ... perception ... volitional formations ... consciousness as the self, does not see the self as possessing consciousness, does not see consciousness as contained within the self, and does not see the self as contained within consciousness

$(M \bar{A}$ 210: 彼不見色是神, 不見神有色, 不見神中有 色, 不見色中有神也, 不見覺, 想, 行, 識是神, 不見 神有議, 不見神中有諳, 不見諳神中有神也).

One does not regard form as the self, or the self as possessing form, or form as being in the self, or the self as abiding in form; one does not regard feeling tone ... perception ... volitional formations ... consciousness as the self, or the self as possessing consciousness, or consciousness as being in the self, or the self as abiding in consciousness.

(Up 1005: gzugs bdag yin, gzugs bdag dang ldan, bdag la gzugs yod, gzugs la bdag gnas zhes yang dag par rjes su mi mthong ste; tshor ba dang, 'du shes dang, 'du byed dang, rnam par shes pa bdag yin, rnam par shes pa bdag dang ldan, bdag la rnam par shes pa yod, rnam par shes pa la bdag gnas zhes yang dag par rjes su mi mthong ste).

This goes to show that the teaching on not self is not confined to the idea of identifying one of the aggregates as the self, as it also covers other modes of relating the self to the aggregates and thereby comprises the notion of a true self as something that exists outside of the aggregates. For such a true self to be of any relevance to the individual at all, it has to relate to at least one of the aggregates in some way. If it is not considered to be identical with an aggregate, such a relation could be posited either by way of owning it, or by being inside of it, or by positioning the aggregate inside of such a self. All of these modalities are covered in the above passages. It follows that the teaching on not self not only recognized self-notions that are based on identifying one or all of the aggregates as the self, leaving little room to posit either a compatibility with belief in a self or a restriction of self-notions to identification with the aggregates. Besides, instructions on not self are such a recurrent feature of the early discourses that the idea that the Buddha was silent on this topic is not particularly compelling. Just to provide one example, the explicit and comprehensive applicability of the teaching of not self can be seen in the following statement, preserved in a range of sources:

All phenomena are not self.

(Dhp 279: sabbe dhammā anattā),
(Gāndhārī Dharmapada 108, Brough 1962/2001, p.134: sarvi dhama anatva),

(Patna Dharmapada 374, Cone 1989, p. 203: sabbadhammā anāttā),

(Udānavarga 12.8, Bernhard 1965, p. 194: sarvadharmā anātmānah),

(T 213, stanza 12.9: 一切法無我).

The formulation adopted here, which recurs regularly in other discourses, makes it unmistakably clear that the teaching on not self applies to all and everything, without exception.

\section{The Four Noble Truths and the Experience of Awakening}

Although the realization of awakening can be understood as in itself a non-conceptual experience, involving a thorough deconstruction of the "world" of experience, its implications can be expressed with concepts, such as, for example, the four noble truths. According to Thompson (2020, p. 145),

Part of the problem is that there is no Buddhist consensus on what the content of the state or experience of awakening is ... already in the early Buddhist texts, we find different and irreconcilable conceptions of the content of the awakening experience that leads to liberation.

It would perhaps be more accurate to indicate that the presumed irreconcilability is the view of several scholars studying the early Buddhist texts, whose conclusions have been contested by other scholars. When relevant texts are viewed from a text-historical perspective, it seems quite possible that the employment of notions like the four truths to convey the implications of awakening were in later times mistaken as descriptions of the actual content of awakening (Anālayo 2021a). Be that as it may, there is a need to distinguish between debated hypotheses and established facts. The characterization of early Buddhist conceptions of the contents of the awakening experience as irreconcilable belongs to the former category; as of now, it is not an established fact.

The proposal to view the teaching on the four noble truths as a way of communicating the awakening experience to others, as exemplified by what tradition considers to have been the first sermon given by the Buddha (Anālayo 2012, 2013) acquires additional significance on considering this fourfold scheme in its historical and cultural context. This crucial doctrine for Buddhist thought appears to have its origin in a medical scheme of diagnosis (Anālayo 2011).

In other words, when deliberating how to convey his realization to those who were to become his first disciples, the Buddha is on record for intentionally avoiding the various 
philosophical and religious ideas current among other spiritual seekers in the ancient Indian setting and preferring to rely on a mode of analysis stemming from ancient Indian medicine. As a result, the perhaps most fundamental teaching of early Buddhist thought is couched in ancient Indian medical terms. Although this does not turn early Buddhism into a science of sorts, it does provide a remarkable reference point for evaluating its compatibility with research in psychology in particular.

Regarding such evaluations, a question here is how far it is meaningful to employ concepts that have arisen under specific conditions in recent centuries in the West to evaluate another culture situated at a substantially different time and place. Thompson (2020, p. 28) portrayed the typical evaluation of religion (presumably not his own), based on Western scientific criteria, in the following manner:

All religions, including Buddhism, when viewed as being about beliefs in supernatural agents (gods, celestial buddhas and bodhisattvas) or supernatural principles (karma), cannot but seem ridiculous in the eyes of science in all the ways today's 'new atheists' never tire of pointing out.

Take Socrates, for example, who was probably a contemporary of the Buddha, roughly speaking. According to what is known about Socrates from later reports (by Aristophanes, Plato, and Xenophon), he believed in gods and an afterlife governed by a principle comparable to the ancient Indian notion of karma (Dillon 2000, p. 539). Does this conflict with him being held in high regard as a philosopher in the current sense of the term? The pre-Socratic Empedocles, whose theory of four elements laid an important foundation for the development of the natural sciences in the West, believed to have experienced former lives as a human being and an animal (Barnes 1979/1982, p. 82). Although his thought could hardly be reckoned to have been "scientific" in the sense the terms is used nowadays, it is not meaningful to disqualify him as "ridiculous." Instead, it would be preferable to appreciate these two eminent Greek thinkers and their significant contributions from the viewpoint of their historical and cultural milieu.

Once that much is granted, however, the same treatment will also have to be afforded to other thinkers from a different cultural setting, such as ancient India. Throughout, there is a need to adjust the standards of evaluation to what is being evaluated, rather than opting for a universalization of subjectivity by taking one's own personal standards as invariably the appropriate reference point. In a different context, Robinson (1972, p. 311) reasoned that there is a danger of structuring "investigation as a process of selecting between alternatives proper to the problematic of Western, and particularly modern, philosophy." Such can then end up being just a matter of "the philosophical housekeeping class."

In other words, the question how far early Buddhism is "rational" or even "scientific" would need to be based on defining these terms in relation to the ancient Indian context, rather than imposing a much later Western viewpoint. If approached from the perspective of its cultural setting, early Buddhism indeed stands out for an emphasis on rational reasoning and for its employment of a medical scheme of diagnosis when formulating what tradition regards as the first and foundational teaching delivered by the Buddha.

\section{The Centrality of Meditation}

A last topic to be taken up in the present exploration is the following assertion by Thompson (2020, p. 2) regarding:

the belief that Buddhism is ... inherently rational and empirical ... or [a] way of life based on meditation. These beliefs, as well as the assumptions about religion and science on which they rest, are mistaken. They need to be discarded.

With all room granted to the necessity of putting into proper perspective some strands of Buddhist modernism for overstating those aspects of Buddhism that are particularly palatable to the West, the above formulation risks becoming as lopsided as the target of its criticism. The exploration thus far, in this article and in Anālayo (2021c), has brought to light dimensions of rationality and utilization of empirical epistemological means, in particular through the cultivation of mindfulness, that are nothing short of remarkable. These features are quite unique in the ancient Indian religious setting and beyond.

Moreover, early Buddhism was indeed prominently a way of life based on meditation. The early discourses show the Buddha himself to have been a dedicated meditator (Anālayo 2017), and his chief teachings can be seen to spring from his meditative practice and realizations (Anālayo 2022). The textual sources also show meditation to have been a central concern among his disciples, both monastic and lay (Anālayo 2020a). The evidence that emerges in this way is not confined to prescriptive material but also covers the descriptive, in the sense of reflecting actual practice, at times in quite an accidental manner.

The instructions in the Satipatthanna-sutta and its parallels are addressed to "monks" (bhikkhu, bhikșu, 比丘, dge slong). This can easily be misunderstood to imply that such instructions were not meant for laity (or nuns). Yet, this form of address just reflects ancient Indian protocols of conversation, where a whole group will be addressed by explicitly naming only some of them (Collett \& Anālayo 2014). The early discourses in fact 
report several cases of highly accomplished lay practitioners (Anālayo 2020a, p. 1941).

Without going so far as to reduce early Buddhism to meditation only, it is nevertheless the case that it accords a central value to a way of life based on meditation. The same may well hold for a considerable number of later traditions. The problem here is a lack of evidence one way or another. Those who dedicate themselves to a life of meditation will avoid living in monasteries, as they naturally prefer hermitages or caves as being more conducive to a meditative lifestyle. Hermitages are usually constructed from material that, particularly in a tropical climate, will not endure for long. Hence, meditators tend not to leave an easily discernible archeological imprint. Yet, many of the developments of Buddhist doctrine in later time can be understood to stand in dialogue with meditation practices and experiences. This is not to deny other agendas, but only to take the position that meditation has indeed been central for the Buddhist way of life at its outset and may well have continued to have been so for quite some time. When Thompson (2020, p. 25) portrays as a wrong idea that "Buddhism at its core is really a psychology based on meditation," then this appears to be actually correct for early Buddhism, rather than being merely an idea created and promoted by nineteenth century Orientalism.

By way of providing an example for the sake of illustration, it would hardly be convincing to claim that there is a need to discard the idea that "charity" or "love" (caritas, agape $\bar{e}$ is a central Christian value, citing a few instances from the inquisition, the crusades, and the persecution of Jews. Instead, such instances need to be contextualized by considering the evidence for the central value accorded to charity or love in the reported teachings of Jesus and many of his later followers. In the same vein, the absence of an interest in meditation in some later Buddhist traditions needs to be contextualized by considering the evidence for the central value accorded to meditation in the reported teachings of the Buddha and many of his followers. In the words of Samuel (2014, p. 570), even though the actual practice of meditation in the different Buddhist traditions "may not be anything like as central to Buddhist practice as Westerners typically assume, but it does take place, and it has played a significant historical role in the development of Buddhist philosophy and practice."

The above considerations apply just to what could be reckoned "formal meditation." The scope of mindfulness goes beyond that. A division of wisdom into three types distinguishes between wisdom produced by hearing (=learning), by reflection, and by cultivation, the last of which can be taken to stand for formal meditation practice. Yet, all three types of wisdom involve mindfulness (Anālayo 2021b). Thus, for example, the centuries of oral transmission of the teachings given by the Buddha and his disciples are a testimony to the continuity of a particular type of mindfulness-related practice. When viewed from this perspective, mindfulness is indeed crucial to a broad range of dimensions of the Buddhist traditions.

In his attempt to counter what he considered to be "Buddhist exceptionalism," Thompson (2020, p. 24) portrayed the target of his criticism in the following way:

There is a popular idea that Buddhism is inherently rational and scientific. People say that Buddhism isn't so much a religion as it is a philosophy or a way of life. Some scientists have described it as 'the most sciencefriendly religion.' It dispenses with the concept of God, upholds direct observation, understands things in terms of cause and effect, maintains that everything constantly changes, and says that there is no essential self or soul.

Yet, such popular ideas, with their occasional overstatements, seem overall to do better justice to the extant evidence for early Buddhism than the presentations by Thompson (2020) and Lopez (2008), which turn out to be based on several misunderstandings (only a selection of which has been taken up here and in Anālayo 2021c, which thus do not provide a comprehensive assessment of the two works).

By way of concluding the present attempt at situating mindfulness at a point of convergence between early Buddhism and research in psychology, based on hopefully having been able to clear up some misunderstandings, the situation could be summed up as follows (Anālayo 2019a, p. 13):

it [is] important to acknowledge that psychology and Buddhist meditation are different knowledge systems with distinct epistemologies and dissimilar final aims. Nevertheless, they converge on a keen interest in understanding the workings of the mind with a view to alleviate unnecessary suffering. This common ground can become an arena for an open dialogue that avoids both a quest for validation and an attempt to trump the other.

Abbreviations AN: Añguttara-nikāya; Dhp: Dhammapada; EĀ: Ekottarika-āgama (T 125); MĀ: Madhyama-āgama (T 26); MN: Majjhima-nikāya; Mp: Manorathapūraṇī; Pj: Paramatthajotikā; $\mathrm{SA}$ : Samyukta-āgama (T 99); S $\bar{A}^{2}$ : Sampyukta-āgama (T 100); SN: Samyutta-nikāya; Sn: Sutta-nipāta; T: Taishō edition; Ud: Udāna; Up: Abhidharmakośopāyikā-ț̄̄kā; Vism: Visuddhimagga

Funding Open Access funding enabled and organized by Projekt DEAL.

\section{Declarations}

Ethical Approval This article does not contain any studies performed by the author with human participants or animals. 
Conflict of Interest The author declares that there is no conflict of interest.

Open Access This article is licensed under a Creative Commons Attribution 4.0 International License, which permits use, sharing, adaptation, distribution and reproduction in any medium or format, as long as you give appropriate credit to the original author(s) and the source, provide a link to the Creative Commons licence, and indicate if changes were made. The images or other third party material in this article are included in the article's Creative Commons licence, unless indicated otherwise in a credit line to the material. If material is not included in the article's Creative Commons licence and your intended use is not permitted by statutory regulation or exceeds the permitted use, you will need to obtain permission directly from the copyright holder. To view a copy of this licence, visit http://creativecommons.org/licenses/by/4.0/.

\section{References}

Anālayo, Bh. . (2011). Right view and the scheme of the four truths in early Buddhism, the Samyukta-āgama parallel to the Sammāditțhisutta and the simile of the four skills of a physician. Canadian Journal of Buddhist Studies, 7, 11-44.

Anālayo, Bh. (2012). The Chinese parallels to the Dhammacakkappavattana-sutta (1). Journal of the Oxford Centre for Buddhist Studies, 3, 12-46.

Anālayo, Bh. (2013). The Chinese parallels to the Dhammacakkappavattana-sutta (2). Journal of the Oxford Centre for Buddhist Studies, 5, 9-41.

Anālayo, Bh. (2015). Healing in early Buddhism. Buddhist Studies Review, 32(1), 19-33. https://doi.org/10.1558/bsrv.v32i1.28962

Anālayo, Bh. (2017). A meditator's life of the Buddha, based on the early discourses. Cambridge: Windhorse Publications.

Anālayo, Bh. (2018). The Bāhiya instruction and bare awareness. Indian International Journal of Buddhist Studies, 19, 1-19.

Anālayo, Bh. (2019a). Adding historical depth to definitions of mindfulness. Current Opinion in Psychology, Special Issue on Mindfulness, 28, 11-14. https://doi.org/10.1016/j.copsyc.2018.09.013

Anālayo, Bh. (2019b). In the seen just the seen: Mindfulness and the construction of experience. Mindfulness, 10(1), 179-184. https:// doi.org/10.1007/s12671-018-1042-9
Anālayo, Bh. (2020a). The centrality of mindfulness-related meditations in early Buddhist discourse. Mindfulness, 11(8), 1935-1942. https://doi.org/10.1007/s12671-020-01381-y

Anālayo, Bh. (2020b). Mindfulness in early Buddhism, characteristics and functions. Cambridge: Windhorse Publications.

Anālayo, Bh. (2021a). The Buddha's awakening. Mindfulness, 12(9), 2141-2148. https://doi.org/10.1007/s12671-021-01649-x

Anālayo, Bh. (2021b). Hearing, reflection, and cultivation: Relating the three types of wisdom to mindfulness. Religion, 12(441), 1-12. https://doi.org/10.3390/rel12060441

Anālayo, Bh. (2021c). Situating mindfulness (1): Early Buddhism and scientific research in psychology. Mindfulness. https://doi.org/10. 1007/s12671-021-01673-x

Anālayo, Bh. (2022). Gotama Buddha: his quest and teachings. In Routledge Handbook of Indian Philosophy (forthcoming).

Barnes, J. (1979/1982). The Presocractic Philosophers. London: Routledge.

Bernhard, F. (1965). Udānavarga. Göttingen: Vandenhoeck \& Ruprecht.

Brough, J. (1962/2001). The Gāndhārī Dharmapada, edited with an introduction and commentary. Delhi: Motilal Banarsidass.

Collett, A., \& Anālayo, Bh. (2014). Bhikkhave and bhikkhu as genderinclusive terminology in early Buddhist texts. Journal of Buddhist Ethics, 21, 760-797.

Cone, M. (1989). Patna Dharmapada. Journal of the Pali Text Society, $13,101-217$.

Dillon, M. (2000). Dialogues with death: The last days of Socrates and the Buddha. Philosophy East and West, 50(4), 525-558.

Lopez, D. S., Jr. (2008). Buddhism \& science, a guide for the perplexed. Chicago: The University of Chicago Press.

Migot, A. (1954). Un grand disciple du Buddha, Sāriputra, son rôle dans l'histoire du Bouddhisme et dans le développement de l'Abhidharma. Bulletin de l'école Française d'extrême Orient, $46,405-554$.

Robinson, R. H. (1972). Some methodological approaches to the unexplained points. Philosophy East and West, 22(3), 309-323.

Samuel, G. (2014). Between Buddhism and science, between mind and body. Religions, 5, 560-579. https://doi.org/10.3390/rel5030560

Thompson, E. (2020). Why I am not a Buddhist. New Haven: Yale University Press.

Publisher's Note Springer Nature remains neutral with regard to jurisdictional claims in published maps and institutional affiliations. 